\title{
MARSILIUS OF PADUA AND ISAAC ABRAVANEL ON KINGSHIP: THE MEDIEVAL ANTECEDENTS OF REPUBLICANISM REVISITED
}

\section{VASILEIOS SYROS}

\begin{abstract}
This article offers a comparative investigation of Marsilius of Padua's and Isaac Abravanel's ideas on kingship. It looks at how these thinkers transform the "authoritative" sources of their respective traditions of political theorizing, i.e., Aristotle's Politics and the Bible respectively, to articulate the notion that ultimate authority within the political community resides with the body of the citizens. It also examines how these two writers' positions on kingship relate to the political realities that prevailed in late medieval Italy. Ultimately, this article will illuminate the medieval antecedents of modern republicanism in the Christian and Jewish political traditions.
\end{abstract}

\section{Keywords}

Medieval and early modern intellectual history and political thought; Jewish political thought; Kingship; Republicanism; Marsilius of Padua; Isaac Abravanel; Aristotle; Ptolemy of Lucca; biblical exegesis.

The best form of rule or type of polity and the significance of kingship for a well-constituted political community are two of the major themes of medieval and early modern political writing. Most Christian, Jewish, and Islamic thinkers subscribe to the theory of kingship as the optimal form of government. This view was not universal, however: Marsilius of Padua (fourteenth century) and Isaac Abravanel (fifteenth-sixteenth centuries), two key figures of the Christian and Jewish political traditions, respectively, challenged with previous ideas on the primacy of kingship and the merits of perpetual rule, thus predating modern republican ideas. My objective is to explore how these thinkers set forth a novel reading of the "authoritative" texts of their respective traditions, i.e., Aristotle's Politics and the Bible, ${ }^{1}$ to

I am grateful to Cedric Cohen Skalli, Zeev Harvey, Daniel Stein Kokin, Eric Lawee, Roberto Lambertini, Menachem Lorberbaum, Cary Nederman, and Miguel Vatter for their comments on portions of the manuscript.

${ }^{1}$ This is not to overlook that Marsilius relies on other ancient (e.g. Cicero) and Christian (e.g. the New Testament and Augustine) sources in addition to Aristotle. The material studied in this paper derives primarily from the fist dictio of the Defensor pacis, an exposition of the key premises of Marsilius' political theory, which is anchored in an Aristotelian framework, although Marsilius does occasionally refer to the Bible and other sources. On the sources of the Defensor pacis, see Marsilius of Padua, The Defender of the Peace, ed. and trans. by Annabel Brett (Cambridge and New York: Cambridge 
argue that ultimate authority resides with the body of the citizens and that the ruler ought to operate as the executive of the civic body. In addition, I will investigate how these two writers' views of kingship relate to the political realities that prevailed in late medieval Italy.

A comparison between Marsilius and Abravanel is subject to certain limitations. First, although Marsilius' Defensor pacis (The Defender of Peace) was translated into the Florentine vernacular in the fourteenth century, there is no evidence that Abravanel had access to that work. ${ }^{2}$ Second, in the early stages of his life, Marsilius was exposed to the political organization of the Italian city-states, and he entered the court of Louis IV of Bavaria (ca. 1287-1347, r. 1314-1347) after the completion of the Defensor pacis in 1324. Abravanel's life followed a different course: he began his career by serving some of the major dynasties of Europe. Already during his time in Portugal he was familiar with political developments in Italy, particularly Florence. This is evidenced by his correspondence with the banking family Da Pisa, based in Florence and other cities in Tuscany, as well as other sources documenting his involvement in trade activities with Tuscany. ${ }^{3}$ Third, the central thrust of the Defensor pacis is to identify the "singular" cause of discord in Marsilius' own day, i.e., the papacy's interference in civic affairs. As such, this work is not a conventional commentary on Aristotle, although its first diccio, the section that outlines the chief principles of Marsilius' political thought, is peppered with citations and references to several of Aristotle's works, especially the Politics. Abravanel, by

University Press, 2005), lii-lv; Charles W. Previté-Orton, "The Authors Cited in the Defensor pacis," in Essays in History Presented to Reginald Lane Poole, ed. Henry W. C. Davis (Oxford: The Clarendon Press, 1927), 405-20. Abravanel, as will be indicated later, does draw upon Aristotle as well, but his discussion of kingship is embedded in his exegesis of the Bible. For the influence of the study of the Bible on the evolution of Jewish culture in fifteenth-century Spain, see the various contributions in The Hebrew Bible in Fifteenth-Century Spain: Exegesis, Literature, Philosophy, and the Arts, ed. Jonathan Decter and Arturo Prats (Leiden and Boston, MA: Brill, 2012).

${ }^{2}$ References to the Defensor pacis (hereafter $D P$ ) are to the edition Marsilius von Padua, Defensor pacis, ed. Richard Scholz (= Fontes iuris Germanici antiqui in usum scholarum ex Monumentis Germanicae Historicis, separatim editi; 7) (Hannover: Hahn, 1932/33). Citations will be to discourse, chapter, and paragraph. I have consulted the following English translations: Marsilius of Padua, The Defender of Peace vol. 2: The Defensor pacis, trans. Alan Gewirth (New York: Columbia University Press, 1956; repr. 2001); Marsilius of Padua, The Defender of the Peace, ed. and trans. Annabel Brett (Cambridge: Cambridge University Press, 2005). For the Florentine translation of the Defensor pacis, see Marsilio da Padova, Il Difenditore della pace. Nella traduzione in volgare fiorentino del 1363, ed. Carlo Pincin (Turin: Fondazione Luigi Einaudi, 1966). Marsilius' reception in early modern Italy is surveyed in Gregorio Piaia, Marsilio da Padova nella Riforma and nella Controriforma: Fortuna ed interpretazione (Padua: Antenore, 1977). Consider also Bernardo Bayona Aznar, Religión y poder: Marsilio de Padua: ¿La primera teoría laica del Estado? (Madrid: Biblioteca Nueva, 2007), 263-333, and Thomas M. Izbicki, "The Reception of Marsilius," in A Companion to Marsilius of Padua, ed. Gerson Moreno-Riaño and Cary J. Nederman (Leiden and Boston, MA: Brill, 2012), 305-33.

${ }^{3}$ Cedric Cohen Skalli, "Don Isaac Abravanel and Leonardo Bruni: A Literary and Philosophical Confrontation," The European Legacy 20 (2015), 492-512, 492. 
contrast, did not develop a systematic political theory nor did he have direct access to Aristotle's Politics, and his political ideas must be gleaned from his commentaries on the Bible.

The present essay is the first sustained attempt to place Abravanel in conversation with Christian political writers, such as Marsilius, in the context of medieval discourse on the nature, purpose, and scope of political authority, the best form of government, and kingship as well as with an eye to the evolution of republican ideas. ${ }^{4}$ Research on the historical, philosophical, and cultural parameters of Abravanel's thinking has centered primarily on its ties to the humanist thought of his time and Christian/Latin political thought. ${ }^{5}$ Yitzhak Baer, for instance, illustrated Abravanel's dual role as a "Court Jew" and a Renaissance Humanist. He highlighted Abravanel's acquaintance with the humanist literature of his own day and discerned affinities between Abravanel's commentaries and some of Seneca's epistles to Lucilius. Baer drew a close link between Abravanel's use of classical literary motifs and his critique of monarchical authority. ${ }^{6}$ Leo Strauss investigated Abravanel's reception of medieval Christian/Latin thought and construed Abravanel's

\footnotetext{
${ }^{4}$ For scholarly literature on the medieval antecedents to modern republicanism, see, e.g.,: Eva M. Maier, Teleologie und politische Vernunft: Entwicklungslinien republikanischer Politik bei Aristoteles und Thomas von Aquin (Baden-Baden: Nomos-Verlag, 2002); Nicolai Rubinstein, "Le origini medievali del pensiero repubblicano del secolo XV," in Politica e cultura nelle repubbliche italiane dal Medioevo all'Età moderna: Firenze, Genova, Lucca, Siena, Venezia, ed. Simonetta Adorni Braccesi and Mario Ascheri (Rome: Istituto storico italiano per l'età moderna e contemporanea, 2001), 1-20 - repr. in idem, Studies in Italian History in the Middle Ages and the Renaissance, vol. 1: Political Thought and the Language of Politics: Art and Politics, ed. Giovanni Ciappelli (Rome: Storia e letteratura, 2004), 365-81; Quentin Skinner, "The Vocabulary of Renaissance Republicanism: A Cultural longue-durée?," in Language and Images of Renaissance Italy, ed. Alison Brown (Oxford: Clarendon Press, 1995), 87-110; Ant[h]ony J. Black, "Christianity and Republicanism: from St. Cyprian to Rousseau," The American Political Science Review 91 (1997), 647-56 - repr. in idem, Church, State and Community: Historical and Comparative Perspectives (Aldershot: Ashgate, 2003), no. XVI; idem, "Republikanismus als europäisches Phänomen," in Verborgene republikanische Traditionen in Oberschwaben, ed. Peter Blickle (Tübingen: Bibliotheca Academica, 1998), 13-24 - English trans. in idem, Church, State and Community, no. XVIII; Ulrich Meier, "Vom Mythos der Republik: Formern und Funktionen spätmittelaltelterlichen Rathausikonographie in Deutschland und Italien," in Mundus in imagine: Bildersprache und Lebenswelten im Mittelalter, ed. Andrea Löther (Munich: Wilhelm Fink, 1996), 345-87, esp. 345-54.

${ }^{5}$ The following survey of previous scholarship is to a large extent based on Cedric Cohen Skalli, "Discovering Isaac Abravanel's Humanistic Rhetoric," Jewish Quarterly Review 97 (2007), 67-99, esp. 67-78; and idem, "Between Yitzhak Baer and Leo Strauss: The Rediscovery of Isaac Abravanel's Political Thought in the Late 1930s," DAAT 88 [= Wissenschaft des Judentums: Judaism and the Science of Judaism; 200 Years of Academic Thought on Religion, ed. George Y. Kohler et al.] (2019): 61-89. Consider also Isaac Abravanel, Letters, ed. and trans. Cedric Cohen Skalli (Berlin and New York: Walter de Gruyter, 2007).

${ }^{6}$ Yitzhak Baer, "Don Isaac Abravanel and His Relation to Problems of History and Politics," Tarbiz 8 (1937), 241-59 [in Hebrew]. Abravanel's debt to Epistle 90 in particular is clearly recognizable and significant.
} 
references to Seneca as indications of his anti-monarchic stance. ${ }^{7}$ Moshel Idel called attention to the influences of Marsilio Ficino's (1433-1499) concept of prisca theologia on Abravanel's literary oeuvre and saw Abravanel's Platonist and Hermetic approach to Kabbalah as reflective of his reception of Ficino's and Giovanni Pico della Mirandola's (1463-1494) humanist ideals. ${ }^{8}$ For Ram Ben-Shalom, Abravanel inaugurated a new literary trend by blending Jewish medieval literature and the Iberian humanist tradition. ${ }^{9}$ Amos Funkenstein discussed Abravanel's views on biblical kingship against the background of Scholastic debates on the distinction between absolute power (potentia absoluta) and ordained power (potentia ordinata). ${ }^{10}$ Eleazar Gutwirth explored the links between Abravanel and Castilian and Portuguese humanist literature by focusing on the introduction to Abravanel's commentary on the Former Prophets. ${ }^{11}$ More recently, Cedric Cohen Skalli engaged in an in-depth analysis of Abravanel's and Leonardo Bruni's (ca. 1370-1444) views on republicanism in comparative perspective. ${ }^{12}$

The present article explores Abravanel's political doctrines in a comparative context and seeks to defy and overcome the dichotomy between Humanism and Jewish philosophy

\footnotetext{
${ }^{7}$ Leo Strauss, "On Abravanel's Philosophical Tendency and Political Teaching," in Isaac Abravanel, Six Lectures, ed. John B. Trend and Herbert Loewe (Cambridge: Cambridge University Press, 1937), 93129 - repr. in idem, Gesammelte Schriften, vol. 2: Philosophie und Gesetz - Frühe Schriften, ed. Heinrich Meier (Stuttgart and Weimar: J. B. Metzler, 1997), 195-227, and, more recently, in Leo Strauss on Maimonides: The Complete Writings, ed. Kenneth Hart Green (Chicago, IL, and London: University of Chicago Press, 2013), 579-613; French trans. by Adrien Barrot "Sur l'orientation philosophique et l'enseignement politique d'Abravanel," Revue de Métaphysique et de Morale 4 (1998) [= Philosophies juives médiévales], 559-84. Consider also Strauss' "Zu Abravanels Kritik des Königtums," in idem, Gesammelte Schriften, vol. 2: Philosophie und Gesetz - Frühe Schriften, ed. Heinrich Meier (Stuttgart: J. B. Metzler, 1997), 233-34 [Eng. trans. by Martin D. Yaffe as "On Abravanel's Critique of Monarchy," in Reorientation: Leo Strauss in the 1930s, ed. Martin D. Yaffe and Richard S. Ruderman (New York: Palgrave Macmillan, 2014), Appendix E (267-68].

${ }^{8}$ Moshe Idel, "Kabbalah and Prisca Theologia in Rabbi Isaac and Yehuda Abravanel's Writings," in The Philosophy of Leone Ebreo: Four Lectures, ed. Menachem Dorman and Zeev Levi (Haifa: HaKibbutz Hameuchad, 1985), 73-112 [in Hebrew].

${ }^{9}$ Ram Ben-Shalom, Facing Christian Culture: Historical Consciousness and Images of the Past among the Jews of Spain and Southern France during the Middle Ages (Jerusalem: Ben-Zvi Institute and the Hebrew University of Jerusalem, 2006); idem, "Myth and Classical Mythology in the Historical Consciousness Medieval Spanish Jewry," Zion 66 (2001), 451-94 [both in Hebrew].

${ }^{10}$ Amos Funkenstein, Perceptions of Jewish History (Los Angeles, CA: University of California Press, 1993), 160-65.

${ }^{11}$ Eleazar Gutwirth, "Consolatio: Don Ishaq Abravanel and the Classical Tradition," Medievalia et Humanistica 27 (2000), 79-98; idem, "Don Ishaq Abravanel and Vernacular Humanism in Fifteenth Century Iberia," Bibliothèque d'Humanisme et Renaissance 60 (1998), 641-71.

12 Cohen Skalli, "Don Isaac Abravanel and Leonardo Bruni." Consider also idem, "Fortune and Providence: A Paradigm in Isaac Abravanel's Encounter with Renaissance Culture," in The Italia Judaica Jubilee Conference, ed. Shlomo Simonsohn and Joseph Shatzmiller (Leiden and Boston, MA: Brill, 2013), 13- 20; and "Discovering Isaac Abravanel's Humanistic Rhetoric." For a refreshing discussion of Abravanel's ties to the humanist tradition, see also the recent intellectual biography published by the same author, Don Isaac Abravanel (Jerusalem: The Zalman Shazar Center, 2017) [in Hebrew].
} 
that has dominated scholarly research on the sources of his political theory. The comparison of Marsilius' and Abravanel's ideas will shed new light on the ways in which Jewish political writers responded to some of the themes that were the focus of political theorizing within the Christian/Latin tradition. ${ }^{13}$

\section{Marsilius on Kingship}

Marsilius (Marsiglio) dei Mainardini was born between 1270 and 1290 in Padua. ${ }^{14}$ The scion of a family of legal experts, he broke away from his family's tradition by choosing to study medicine instead of law. Marsilius studied arts and medicine in Paris, most probably after an initial period of study under Peter of Abano (ca. 1250-1315), a major natural philosopher and physician, at the University of Padua. He was elected rector of the University of Paris for the period of December 1312 to March 1313. In that capacity, Marsilius had access not only to the council of the French king but also to the curia in

\footnotetext{
${ }^{13}$ On the evolution of the Jewish political tradition in general, see the discussions in Julie E. Cooper, "The Turn to Tradition in the Study of Jewish Politics," Annual Review of Political Science 19 (2016): 67-87; Menachem Lorberbaum, "Medieval Jewish Political Thought," in The Cambridge Companion to Medieval Jewish Philosophy, ed. Daniel H. Frank and Oliver Leaman (Cambridge: Cambridge University Press, 2003), 176-200; Michael Walzer, "Introduction: The Jewish Political Tradition" in The Jewish Political Tradition, vol. 1: Authority, ed. Michael Walzer et al. (New Haven, CT, and London: Yale University Press, 2000), xxi-xxxi; Abraham Melamed, "Is There a Jewish Political Thought [Philosophy]? The Medieval Case Reconsidered," Hebraic Political Studies 1 (2005), 24-56 - repr. in idem, Wisdom's Little Sister: Studies in Medieval and Renaissance Jewish Political Thought (Boston, MA: Academic Studies Press, 2012), 16-49 (henceforth cited as Wisdom's Little Sister/2012); idem, "Medieval and Renaissance Jewish Political Philosophy," in History of Jewish Philosophy, ed. Daniel H. Frank and Oliver Leaman (London and New York: Routledge, 1997), vol. 2: 415-49; The Quest for Utopia: Jewish Political Ideas and Institutions Through the Ages, ed. Zvi Gitelman (Armonk, NY: M. E. Sharpe, 1992); "An Introduction to the Jewish Political Tradition," in Daniel J. Elazar and Stuart A. Cohen, The Jewish Polity: Jewish Political Organization from Biblical Times to the Present (Bloomington, IN: Indiana University Press, 1985), 1-41; Daniel J. Elazar, "Introduction," and "Covenant as the Basis of the Jewish Political Tradition," in Kinship and Consent: The Jewish Political Tradition and Its Contemporary Uses, ed. Daniel J. Elazar (Ramat Gan [Israel]: Turtledove Publishing, 1981; repr. Washington, DC: University Press of America, 1983), 1-17 and 21-56, respectively; idem, "Jewish Political Studies as a Field of Inquiry," Jewish Social Studies 36 (1974), 220-33. Consider also Political Hebraism: Judaic Sources in Early Modern Political Thought, ed. Gordon Schochet et al. (Jerusalem and New York: Shalem Press, 2008); Alan L. Mittleman, The Scepter Shall Not Depart from Judah: Perspectives on the Persistence of the Political in Judaism (Lanham, MD: Lexington Books, 2000), 19-45.

${ }^{14}$ For Marsilius' life and works, see Vasileios Syros, Marsilus of Padua at the Intersection of Ancient and Medieval Traditions of Political Thought (Toronto: University of Toronto Press, 2012), 15-24; Frank Godthardt, "The Life of Marsilius of Padua," and William J. Courtenay, "Marsilius of Padua at Paris," in A Companion to Marsilius of Padua, 13-55 and 57-70, respectively; Frank Godthardt, Marsilius von Padua und der Romzug Ludwigs des Bayern: Politische Theorie und politisches Handeln (Göttingen: Vandenhoeck \& Ruprecht, 2011); Bayona, Religión y poder, 25-43; Carlo Pincin, Marsilio (Turin: Giappichelli, 1967), 21-54; Carlo Dolcini, Introduzione a Marsilio da Padova (Rome and Bari: Laterza, 1995).
} 
Avignon. ${ }^{15}$ During his stay in Paris, Marsilius befriended John of Jandun (ca. 1280-1328), a Master of Arts at Paris who taught at the Collège de Navarre from 1315 to 1324 and authored a number of commentaries on Aristotle as well as a panegyric of Paris under the title De laudibus Parisius (1323), which he dedicated to King Charles IV (Charles le Bel, 1294-1328, r. 1322-28). ${ }^{16}$ John XXII's (1214-1334) appointment to the Avignon papacy awoke in Marsilius the hope of an ecclesiastical career in his native Padua. Between 1316 and 1318, he received several promises from Pope John of an ecclesiastical benefice, but his hopes were never realized.

Marsilius' interest in the political life of his time and his aspirations for a political career did not wither away, however: in 1319, he participated in a delegation sent by the Milanese signore Matteo I Visconti (1250-1322) to Charles, Count of La Marche (the later Charles IV of France), for the purpose of forging an alliance. Matteo had been excommunicated in 1317 by John XXII because of his opposition to Robert of Anjou (1278-1343), the king of Naples, whom John had appointed as vicar over the regnum italicum. With Cangrande I della Scala (1291-1329) of Verona, Matteo made a stand against Robert and petitioned Charles for support, offering him the leadership of the Ghibelline party in return. ${ }^{17}$ The French declined this proposal, and Marsilius returned to his academic activities in Paris. ${ }^{18}$ In 1324, ${ }^{19}$ Marsilius completed his magnum opus, the Defensor pacis, which he dedicated to Louis IV of Bavaria (1287-1347). ${ }^{20}$ Although Marsilius claimed to be the sole author of the Defensor pacis, ${ }^{21}$ the treatise was long considered to be the joint product of Marsilius and Jandun. ${ }^{22}$ However, there exist crucial

\footnotetext{
15 On Marsilius' Parisian years, see William J. Courtenay, "University Masters and Political Power: The Parisian Years of Marsilius of Padua," in Politische Reflexion in der Welt des späten Mittelalters, ed. Martin Kaufhold (Leiden and Boston, MA: Brill, 2004), 209-23.

16 For Jandun's life and works, see Jean-Baptiste Brenet, Transferts du sujet: La noétique d'Averroès selon Jean de Jandun (Paris: Vrin, 2003); 11-13; Ludwig Schmugge, Johannes von Jandun (1285/891328): Untersuchungen zur Biographie und Sozialtheorie eines lateinischen Averroisten (Stuttgart: Anton Hiersemann, 1966), 1-38.

${ }^{17}$ Charles W. Previté-Orton, "Marsilius of Padua and the Visconti," English Historical Review 44 (1929), 278-79.

${ }^{18}$ Schmugge, Johannes von Jandun, 28-29.

${ }^{19}$ DP III.iii.

${ }^{20}$ In $D P$ I.i.6

${ }^{21} D P$ I.i.6.

22 See, for example, the bull of Pope John XXII Licet iuxta doctrinam (23.10.1237) in Const. VI, no. 361, in which Marsilius and John as the alleged authors of the Defensor pacis are condemned as heretics. The authorship of the work has been the subject of a long-standing scholarly debate. The co-authorship has been advocated by Noël Valois, "Jean de Jandun et Marsile de Padoue, auteurs du Defensor pacis," Histoire littéraire de la France 33 (1906), 528-623. On the other hand, there is a substantial body of scholarship that has challenged this interpretation: Alan Gewirth, "Philosophy and Political Thought in the Fourteenth Century," in The Forward Movement of the Fourteenth Century, ed. Francis L. Utley
} 
differences between Marsilius' and Jandun's political ideas that render the assumption of their co-authorship of the work untenable.

In the summer of 1326, Marsilius and Jandun fled from Paris to the court of Louis of Bavaria. On 9 April 1327, Marsilius and Jandun were called before the papal court in Avignon to account for the publication of the Defensor pacis. When they did not obey John XXII's request, the pope issued the bull Licet iuxta doctrinam on 23 October of the same year, which identifies five statements of the Defensor pacis as fallacious and heretical. In the spring of 1327, not long after the pope condemned the Defensor pacis, Louis of Bavaria launched his Italian expedition. Marsilius and Jandun accompanied Louis, and it is possible that Marsilius used his personal connections to the Ghibellines to back Louis's Italian venture. A series of events in Rome hint at Marsilus' active involvement in the event surrounding Louis's coronation as emperor. In 1329 political changes and increasing opposition forced him to leave Italy and return with Louis' retinue to Nuremberg. Marsilius accompanied Louis and spent the years before his death in 1343 as Louis' personal physician.

Marsilius' political theory is predicated on the notion that the legislator humanus, i.e. the entire body of the citizens - or, its "weightier" (preponderant) part (pars valentior) is the ultimate source of sovereign authority. ${ }^{23}$ The ruler is the executive organ of the legislator humanus that operates with the authority granted to him by the latter. ${ }^{24}$ Marsilius relies on Aristotle's teaching about the sovereignty of the multitude as expounded in Book

(Columbus, OH: Ohio State University Press, 1961), 125-64, 141-50; idem, "John of Jandun and the Defensor pacis," Speculum 23 (1948), 267-72; Carlo Dolcini, "Marsilio da Padova e Giovanni di Jandun," in Storia della chiesa, vol. 11: La crisi del Trecento e il papato avignonese (1274-1378) (Cinisello Balsamo: San Paolo [?], 1994), 435-46; Ephraim Emerton, The Defensor pacis of Marsiglio of Padua: A Critical Study (Cambridge, MA: Harvard University Press, 1920; repr. 1951), 17-19.

${ }^{23}$ E.g., DP I.xii.2-3; xiii.1, 8; xv.2-7; xviii.1. Marsilius' notion of the pars valentior has been a controversial topic in Marsilian research. Some scholars have construed the phrase to signify the numerical majority. According to another line of interpretation, Marsilius uses the term to designate the group of the most outstanding citizens. Though in certain places in the Defensor pacis the term is used with quantitative connotations, in the very context of the definition of the legislator humanus Marsilius incorporates both the qualitative and quantitative criteria. A fuller discussion of these issues can be found in Vasileios Syros, Die Rezeption der aristotelischen politischen Philosophie bei Marsilius von Padua (Leiden and Boston, MA: Brill, 2007), 193-212. A survey of previous scholarship appears in Marsilio da Padova, ed. Elvio Ancona and Franco Todescan (Padua: CEDAM, 2007), 57-61. It is more plausible, though, that Marsilius' objective is to articulate a model of political organization that can be tailored to different realities. Hence, he employs an "elliptical" manner of writing and deliberately refrains from offering an exact definition of the pars valentior. On this point, see also Cary J. Nederman, Community and Consent: The Secular Political Theory of Marsiglio of Padua's Defensor pacis (Lanham, MD: Rowman \& Littlefield, 1995), 15, 19-20; Conal Condren, The Status and Appraisal of Classic Texts: An Essay on Political Theory, Its Inheritance, and the History of Ideas (Princeton, NJ: Princeton University Press, 1985), 189-97.

${ }^{24}$ DP I.xv.4. 
III of the Politics. However, whereas Aristotle's doctrine concerns the task of appointing, inspecting, and calling the ruler or rulers and various officeholders to account, Marsilius extends its application to legislation. ${ }^{25}$

Carrying on the ancient Greek tradition, Aristotle portrays the ideal lawgiver (nomothêtēs) as a sagacious individual who is involved in the founding of a new political order and promulgates written and unwritten laws. ${ }^{26}$ Marsilius, by contrast, challenges this idea and insists that the "primary and proper sufficient cause" of the law, is the entire body (universitas) of the citizens or their "weightier part" (pars valentior) that adequately represents it. ${ }^{27}$ Marsilius' goal is to outline a universal model of political organization which is adaptable to changing social exigencies and constitutes the basis of all legitimate types of government (kingship, aristocracy, and polity). Although only once in the Defensor pacis Marsilius suggests that kingship is "perhaps" the best form of rule ${ }^{28}$ he does not reveal a preference for a specific governmental form nor does he share his predecessors' predilection for kingship. He argues instead that the government can assume different forms depending on the circumstances and political exigencies. ${ }^{29}$

Marsilius' avowed aim in the Defensor pacis is to expose the singular cause of strife of his own day. Such strong preoccupation with the efficient causes of political phenomena has important ramifications for Marsilius' concept of unity: unlike Aristotelian commentators and Scholastic political writers who are concerned with the moral implications of civic unity, Marsilius focuses on its functional aspects. As he phrases it, the unity of a city or kingdom is a unity of order, not an absolute unity. Rather, it is a plurality of several individuals who are called "one" not because they are literally one in number, but because they exist for a certain purpose, namely the task of governing. ${ }^{30}$ Marsilius infers from this that it is necessary for the political community to have only one supreme government or governing agency with respect not to the number of rulers but to office. He

${ }^{25}$ For further discussion, see Vasileios Syros, "The Principle of the Sovereignty of the Multitude in the Works of Marsilius of Padua, Peter of Auvergne and Some Other Aristotelian Commentators," in The World of Marsilius of Padua, 227-48, esp. 245-47. In my presentation of Aristotle's and Marsilius' ideas about the rule and authority of the whole citizen body, I use the concept of sovereignty to refer to the highest executive authority, but do not mean to associate it with the way it is defined and deployed by later political theorists, such as Jean Bodin (1530-1596), Hugo Grotius (1583-1645), and Thomas Hobbes (1588-1679).

${ }^{26}$ Politics $1283^{\mathrm{b}} 38 ; 1286^{\mathrm{a}} 22 ; 1273^{\mathrm{b}} 26-74^{\mathrm{b}} 26 ; 1266^{\mathrm{a}} 39-^{\mathrm{b}} 8 ; 1266^{\mathrm{b}} 9 ; 1327^{\mathrm{b}} 36 ; 1332^{\mathrm{b}} 9 ;$ Nicomachean Ethics 1102 ${ }^{\mathrm{a}} 7-12$.

${ }^{27} D P$ I.xii.3.

${ }^{28}$ DP I.ix.5. See also Alan Gewirth, Marsilius of Padua and Medieval Political Philosophy (New York: Columbia University Press, 1951), 117.

${ }^{29} \mathrm{I}$ am indebted to Miguel Vatter for earlier discussions on this point.

${ }^{30}$ DP I.xvii. 11. 
therefore allows for the possibility of a single government being composed of more than one individual, as is the case with the aristocracy and polity. ${ }^{31}$

For a fuller understanding of Marsilius' conception of the ideal ruler, it is instructive to look more closely at chapter XIII.2 of the Defensor pacis, which argues for the superiority of elective over hereditary monarchy. Marsilius' treatment of this topic must be viewed against the background of the rise of the signoria, an issue that sparked intense debates at Padua on the legitimacy of the rule by one person vis-à-vis communal government. ${ }^{32}$ Just a few years before the publication of the Defensor pacis, in July 1318, and under the threat of invasion of their city by Cangrande della Scala of Verona, the Paduans elected Giacomo da Carrara as their first signore and entrusted him supreme judicial authority, the command of the army, and the administration of the finances. ${ }^{33}$

Marsilius puts forward a series of arguments aimed to illustrate the significance of election as the foundation of salutary and lasting rule. He also highlights the perils of

${ }^{31}$ DP I.xvii.2.

32 See also John K. Hyde, Society and Politics in Medieval Italy: The Evolution of the Civil Life, 1000-1350 (London: Macmillan, 1973), 192-93; idem, Padua in the Age of Dante (Manchester: Manchester University Press, 1966), 307-8; and Nicolai Rubinstein, "Political Theories in the Renaissance," in The Renaissance: Essays in Interpretation, ed. André Chastel et al. (London and New York: Methuen, 1982), 160-61. On the rise of the signoria, consult Trevor Dean, "The Rise of the Signori," in The New Cambridge Medieval history, vol. 5: c. 1198-c. 1300, ed. David Abulafia (Cambridge: Cambridge University Press, 1999), 458-78; Philip J. Jones, The Italian City-State: From Commune to Signoria (Oxford: Oxford University Press, 1997); Ovidio Capitani, "Dal comune alla signoria," in Comuni e Signorie: Istituzioni, società e lotte per l'egemonia, ed. Ovidio Capitani et al. (Turin: UTET, 1981), 135-75; Lauro Martines, Power and Imagination: City-States in Renaissance Italy (New York: A. A. Knopf, 1979), 94-110; Ernesto Sestan, "Le origini delle signorie cittadine: un problema storico esaurito?" Bullettino dell'Istituto Storico Italiano per il Medio Evo e Archivio Muratoriano 73 (1961), 41-69 - repr. in La crisi degli ordinamenti comunali e le origini dello stato del Rinascimento, ed. Giorgio Chittolini (Bologna: Il Mulino, 1979), 53-75 - German trans. by Lilo de Negri "Die Anfänge der städtischen Signorien: ein erschöpfend behandeltes historisches Problem?" in Altständisches Bürgertum, vol 1: Herrschaft und Gemeinverfassung, ed. Heinz Stoob (Darmstadt: Wissenschaftliche Buchgesellschaft, 1978), 346-79; Francesco Ercole, Dal comune al principato: Saggi sulla storia del diritto pubblico del Rinascimento italiano (Florence: Vallecchi, 1929); Maude V. Clarke, The Medieval City State: An Essay on Tyranny and Federation in the Later Middle Ages (London, Methuen \& Co, 1926; repr. Cambridge/New York: Speculum Historiale/Barnes \& Noble, 1966), 99-146; Ernst Salzer, Ueber die Anfaenge der Signorie in Italien: Ein Beitrag zur italienischen Verfassungsgeschichte (Berlin: Ebering, 1900; repr. Vaduz: Kraus Repr., 1965).

33 Jacopo Zennari, "Giacomo II da Carrara, signore di Padova 1345-1350," Bollettino del Museo Civico di Padova 13 (1910), 101-23; 14 (1911), 1-55. For the history of the Carrara regime, see Padova carrarese, ed. Oddone Longo (Padua: Il poligrafo, 2005); Benjamin G. Kohl, Padua under the Carrara, 1318-1405 (Baltimore, MD: Johns Hopkins University Press, 1998); idem, "Government and Society in Renaissance Padua," Journal of Medieval and Renaissance Studies 2 (1972), 205-21 - repr. in idem, Culture and Politics in Early Renaissance Padua (Aldershot and Burlington, VT: Ashgate, 2001); Andrea Di Salvo, 'L'affermazione della signoria cittadina nella percezione dei contemporanei: L'esempio dei Carraresi a Padova nella prima metà del Trecento' (Tesi di dottorato, Università Ca' Foscari Venezia, 1997); Donato Gallo, 'L'epoca delle signorie: Scaligeri e Carraresi (1317-1405),' in Monselice: Storia, cultura e arte di un centro 'minore' del Veneto, ed. Antonio Rigon (Treviso: Canova, 1994), 173-89; Silvana Collodo, Una società in transformazione: Padova tra XI e XV secolo (Padua: Antenore, 1990); Luigi Montobbio, Splendore e utopia nella Padova dei Carraresi (Venice: Corbo e Fiore, 1989). 
hereditary kingship: dynastic succession does not necessarily produce a perfect or adequate leader, whereas election is the best way to assess the qualities and skills of the prospective ruler. ${ }^{34}$ Novelty increases admiration and respect, especially when the new ruler comes from another region or city; the people's respect for him, in turn, will increase their obedience to the government and the laws. ${ }^{35}$ Last but not least, the elected sovereign is more likely to pursue his duties more diligently; he will be more virtuous and will fear punishment through his successors. He will work to ensure that his children are deserving of election in the future and that they are virtuous and well-trained. His children, therefore, will strive to perform their duties and cultivate the qualities and skills requisite for effective political agency. ${ }^{36}$ Intriguingly, an earlier version of the Defensor pacis includes a praise of the doges of Venice for their exemplary government, which was omitted in later versions of the work. $^{37}$

Moreover, Marsilius enumerates the merits of elective monarchy and to addresses potential objections against election. His arguments cluster around three key aspects: (a) the qualities of the would-be ruler and the character of his rule; (b) his relations with his subjects; and (c) the advantages and disadvantages of election in general. The elected ruler will best serve the common benefit, because the legislator humanus always strives to elect a person able to foster the well-being of the entire political community. ${ }^{38} \mathrm{He}$ will provide for the common advantage in order to showcase his individual and civic virtues ${ }^{39}$ and ensure honor and fame for himself, his memory, and his posterity. ${ }^{40}$ Further, he is bound to act in a less despotic way than a hereditary ruler, because he is more prudent, is less able to do wrong with impunity, and will be more easily monitored and corrected. ${ }^{41}$

In line with Aristotle, Marsilius points out that it is rare to find an individual or family so pre-eminent in virtue or in benevolence. ${ }^{42}$ Hence, he believes that an elective monarch is more likely to secure peace and tranquility. Drawing on Aristotle's theory of

\footnotetext{
${ }^{34}$ DP I.xvi.12. On Marsilius' conception of the ideal ruler, see DP I.xiv; and for a fuller discussion Vasileios Syros, "Marsilius of Padua on Princely Virtues and Aristotle's Absolute Ruler," Archiv für mittelalterliche Philosophie und Kultur 13 (2007), 212-29.

${ }^{35}$ DP I.xvi.16.

${ }^{36} D P$ I.xvi.13.

37 On this point, see Marsilius of Padua, The Defensor Pacis, ed. Charles W. Previté-Orton (Cambridge: Cambridge University Press, 1928), 80.
${ }^{38}$ DP I.xvi.11.
${ }^{39}$ DP I.xi.18.
${ }^{40} D P$ I.xvi.14
${ }^{41} D P$ I.xvi.15.

${ }^{42}$ DP I.xvi. 17.
} 
constitutional change, ${ }^{43}$ he argues that resentment and hostility toward the ruler and sedition grow when citizens realize that their rulers are men of less ability than themselves and that they themselves are excluded from the administration of civil affairs. This danger is minimized in the case of elective succession, because the citizens are unlikely to engage in plots against the ruler who they themselves have chosen unless they have been gravely wronged; moreover, they will entertain the hope that they themselves might, in due time, be elected to rule. ${ }^{44}$ Finally, Marsilius points out that elected rulers are more likely to dispense justice impartially and more efficiently and display courage and bring powerful individuals to justice. ${ }^{45}$

These considerations lead Marsilius to an implicit repudiation of Aristotle's notion of the absolute ruler. Aristotle envisions the ideal ruler as an individual who surpasses the other members of the community in virtue and political capacity, governs according to his own will, and needs no laws because he himself is the embodiment of justice. ${ }^{46}$ Marsilius, on the other hand, contends that only few men are unsusceptible to ignorance and perverted emotions and that the human soul is sometimes afflicted by vices: thus, no man can be the incarnation of the law. ${ }^{47}$ Only when a ruler complies with the laws can his judgment be immune to ignorance and perverted emotions. ${ }^{48}$

In Marsilius' view, then, the main differences between temperate and corrupt regimes concern the extent to which they conform to laws conducive to the common good and operate in accordance with the consent of the civic body. ${ }^{49}$ Thus, the more a monarch rules over "voluntary" subjects and adheres to laws that serve the public benefit, the more he approximates the archetype of the legitimate and righteous king. ${ }^{50}$ Only election can produce the best candidate for rulership. ${ }^{51}$ Elected monarchs may be appointed for the term of one ruler's lifetime only; for the lifetime of one ruler and that of one of his successors, or even for a limited period specified on a case-by-case basis. They may be granted full control

\footnotetext{
${ }^{43}$ Politics $1264^{\mathrm{b}} 8$.
}

${ }^{44} D P$ I.xvi.21.

${ }^{45}$ DP I.xvi.23.

46 Aristotle's views on the ideal/absolute ruler are discussed in Richard G. Mulgan, "A Note on Aristotle's Absolute Ruler," Phronesis 19 (1974), 66-69; idem, "Aristotle and Absolute Rule" Antichthon 8 (1974), 21-28; Pierre Carlier, 'La notion de pambasileia dans la pensée politique d'Aristote,' in Aristote et Athènes, ed. Marcel Piérart (Fribourg: Séminaire d'histoire ancienne de l'Université de Fribourg, 1993), 103-18.
${ }^{47}$ DP I.xi.6.
${ }^{48}$ DP I.xi.5.
${ }^{49} D P$ I.ix.5.
${ }^{50} D P$ I.ix.5.
${ }^{51} D P$ I.ix.7. 
over every aspect of government; or, alternately, a ruler might be elected for the sole purpose of being in command of the army. ${ }^{52}$

Marsilius is certainly not unique in his advocacy of election. Indeed, there exists a considerable amount of Scholastic literature that highlighted the relative merits of election as a means of eliciting popular support. Thomas Aquinas (ca. 1224-1274), for example, believes that as long as the nobility and people have a say in government, the likelihood that the king will degenerate into a tyrant will be minimized and the people will feel that they participate in the pursuit of the common interest. ${ }^{53}$ Engelbert of Admont (ca. 1250-1331), albeit defending supremacy of imperial rule, maintains that the endurance of any type of rule or regime should be contingent on the participation of the Many. Engelbert mentions Caesar as an example of a ruler who opposed the participation of the Senate and became a tyrant. $^{54}$

A more profound commitment to republican ideals is found in a number of medieval political treatises, which were written in response to debates about the decadence of communal government and the transition to seigneurial rule. A strong precedent for Marsilius' ideas was set by Ptolemy (Bartolomeo/Tolomeo) of Lucca (ca. 1240-1327) in his De Regimine principum (On the Government of Rulers), the continuation of Thomas Aquinas' De regno ad regem Cypri (On Kingship to the King of Cyprus). ${ }^{55}$ Ptolemy comes

\footnotetext{
${ }^{52}$ DP I.ix.5.
}

53 James M. Blythe, “Civic Humanism' and Medieval Political Thought," in Renaissance Civic Humanism, ed. James Hankins (Cambridge: Cambridge University Press, 2000), 30-74, 62.

${ }^{54}$ Blythe, "'Civic Humanism' and Medieval Political Thought," 42-43.

55 Cohen Skalli, "Don Isaac Abravanel and Leonardo Bruni," 17-18, has also drawn attention to general affinities with Ptolemy of Lucca's political ideas. On the authorship and content of the De regimine principum, see Ptolemy of Lucca, On the Government of Rulers: De Regimine Principum; With Portions Attributed to Thomas Aquinas, trans. James M. Blythe (Philadelphia, PA: University of Pennsylvania Press, 1997) (henceforth cited as On the Government of Rulers), 1-5; Alfred O'Rahilly, "Notes on St. Thomas, IV-De Regimine Principum; V-Tholomeo of Lucca, the Continuator of the De Regimine Principum," The Irish Ecclesiastical Record ser. 5, 31 (1928), 396-410, 606-14, respectively. On Ptolemy's life and works, consult James M. Blythe, The Life and Works of Tolomeo Fiadoni (Ptolemy of Lucca) (Turnhout: Brepols, 2009), 155-77. Ptolemy's political ideas and with a view to the reception of Aristotle's political thought are discussed in the following studies by James M. Blythe: The Worldview and Thought of Tolomeo Fiadoni (Ptolemy of Lucca) (Brepols: Turnhout, 2009); "Aristotle's Politics and Ptolemy of Luca," Vivarium 40 (2002), 103-36; and Ideal Government and the Mixed Constitution in the Middle Ages (Princeton, NJ: Princeton University Press, 1992). Consider also Delphine Carron[-Faivre], "Unde dominium exordium habuit. Origine et légitimation du pouvoir politique chez Ptolémée de Lucques," in The Legitimation of Political Power Medieval Thought (forthcoming); "Le pouvoir politique avant et après le péché originel chez Ptolémée de Lucques († 1327)," in Adam, la nature humaine, avant et après: Épistémologie de la Chute, ed. Gianluca Briguglia and Irène Rosier-Catach (Paris: Publications de la Sorbonne, 2016), 231-53. For a reappraisal of Ptolemy's theory with a view to his use of Roman Republican sources, see Cary J. Nederman and Mary E. Sullivan, "Reading Aristotle through Rome: Republicanism and History in Ptolemy of Lucca's De regimine principum," European Journal of Political Theory 7 (2008), 223-40. Consider also Charles T. Davis, "Roman Patriotism and Republican 
close to Marsilius (and Abravanel) in opposing kingship and, in general, any kind of permanent rule. He notes that Aristotle distinguishes two modes of rule, political and despotic, thereby equating royal and despotic rule. In regal government (regimen regale), the king himself carries the laws inscribed in his heart and is restrained solely by the directive force of natural law. ${ }^{56}$ The head or chief of a constitutional government (rector), by contrast, must abide by statutes and laws promulgated by the civic body. Furthermore, they are bound by oaths and subject to penalties if they are found to have acted or judged contrary to the laws. Ptolemy also outlines the principles for the occupation of the offices: alternation; brief terms; and remuneration. ${ }^{57}$

Marsilius' conception of the paradigmatic political order exhibits a number of common features with Padua's political organization in the period of its communal government. ${ }^{58}$ Ultimate authority in Padua resided with the body of the citizens (comunanza), which was represented by the Great Council (Consiglio Maggiore), which Marsilius perceives to be the equivalent of the pars valentior. The city's highest administrative officer was the podestà, usually a nobleman of foreign descent, who was elected and appointed by a special committee appointed by the Consiglio Maggiore. The podestà took an oath to abide by the statutes of the city; his primary function was to handle

Propaganda: Ptolemy of Lucca and Pope Nicholas III," Speculum 50 (1975), 411-33; idem, "Ptolemy of Lucca and the Roman Republic," Proceedings of the American Philosophical Society 118 (1974), 30-50 - both repr. in idem, Dante's Italy and Other Essays (Philadelphia, PA: University of Pennsylvania Press, 1984), 224-53 and 254-89, respectively. Bee Yun has challenged previous interpretations of Ptolemy as a champion of civic republicanism and proposes instead that his views on government were animated by his pro-papal sentiments. See his "Ptolemy of Lucca - a Pioneer of Civic Republicanism? A Reassessment," History of Political Thought 29 (2008), 417-39; and "Ptolemy of Lucca's Distrust in Politics and the Medieval Discourse on Government," in Trust and Happiness in the History of European Political Thought, ed. László Kontler and Mark Somos (Leiden and Boston: Brill, 2017), 33-52.

56 "De regno ad regem Cypri," in Sancti Thomae de Aquino Opera Omnia (= Editio Leonina; 42), ed. Antoine Dondaine (Rome: Editori di San Tommaso, 1979), II.8.6; IV.1.3; On the Government of Rulers, $122-23,216-7$.

57 "De regno ad regem Cypri," II.8.1-6; IV.1.2-6; IV.8.5-6; On the Government of Rulers, 120-23, $216-18,239$.

${ }^{58}$ For Marsilius as an apologist for imperial rule, see Jeannine Quillet, La philosophie politique de Marsile de Padoue (Paris: Vrin, 1970), 84-91; George Garnett, Marsilius of Padua and the Truth of History' (Oxford and New York: Oxford University Press, 2006), 11-12. According to another line of interpretation, Marsilius' advocacy of republican ideas is to be seen in the context of the late medieval Italian city-republics. On this see, e.g., Alan Gewirth, Marsilius of Padua, 23-31; 196-8; idem, "Republicanism and Absolutism in the Thought of Marsilius of Padua," Medioevo 5 (1979), 23-48; Quentin Skinner, The Foundations of Modern Political Thought, vol. 1: The Renaissance (Cambridge: Cambridge University Press, 1978), 60-5; Syros, Die Rezeption der aristotelischen politischen Philosophie bei Marsilius von Padua, 216-19, 238-39. See also the discussions in Gianfranco Maglio, L'idea costituzionale nel Medioevo: Dalla tradizione antica al 'costituzionalismo cristiano' (Negarine di S. Pietro in Cariano [Verona]: Gabrielli Editori, 2006), 137-61; and Cary J. Nederman, "From Defensor pacis to Defensor minor: the Problem of Empire in Marsiglio of Padua," History of Political Thought, 16 (1995), 313-29. 
criminal and civil cases based on those same statutes. His authority was circumscribed by multiple councils: his actions and decisions were scrutinized at the end of his tenure; if he was found guilty of transgressions or abuse of power, he was subject to penalties. ${ }^{59}$

In similar fashion, Marsilius insists that the governing part (pars principans) of the political community must be elected by the civic body. Thus, the ruler's duty is the enforcement of justice and application of the laws; ${ }^{60}$ otherwise he will face suspension, deposition, and correction according to three criteria, i.e., the gravity, frequency, and legal determination of his demerit or misdeed. ${ }^{61}$ As was the case with the Paduan podestà, Marsilius' model ruler operates as a judge who is animated by respect for the laws and guide by his prudence, or uses equity in cases not foreseen by the law. ${ }^{62}$ Marsilius depicts the ruler as a sort of administrator - indeed, as an executive in the truest sense of the word -- and the guarantor of justice, patterned more after the podestà of the Italian city-states than the kings of the European monarchies. ${ }^{63}$

\section{Abravanel on Kingship}

The son of a financial agent to the Portuguese Court, Abravanel was born in 1437 in Lisbon and died in 1508 in Venice. ${ }^{64}$ He served as King Afonso V of Portugal's (1432-

${ }^{59}$ For further discussion, see Syros, Die Rezeption der aristotelischen politischen Philosophie bei Marsilius von Padua, 214-19; Hyde, Padua in the Age, 210-11.

${ }^{60}$ DP I.xv.4.

${ }^{61} D P$ I.xviii.2-7.

${ }^{62}$ DP I.xiv.3.

${ }^{63}$ DP I.iv.2. See also I.v.8; xvii.1-4; II.viii.6.

${ }^{64}$ On Abravanel's life and works, see e.g. Eric Lawee, Isaac Abarbanel's Stance Toward Tradition: Defense, Dissent, and Dialogue (Albany, NY: State University of New York Press, 2001), 9-25; Benjamin Richler, "Isaac Abravanel's 'Lost' Commentary on Deuteronomy," in Jewish Studies at the Turn of the Twentieth Century, ed. Judit Targarona Borrás and Angel Sáenz-Badillos (Leiden and Boston, MA: Brill, 1999), 1: 199-204; Benzion Netanyahu, Don Isaac Abravanel, Statesman \& Philosopher (Ithaca, NY: Cornell University Press, $5^{\text {th }}$ ed. 1998), 3-91; Roland Goetschel, Isaac Abravanel conseiller des princes et philosophe, 1437-1508 (Paris: Albin Michel, 1996); Filena Patroni Griffi, "Circolazione di élites nel Mediterraneo occidentale: Le attività economiche degli Abravanel in Italia meridionale (14921543)," Revista d'historia medieval 6 (1995): 111-21, esp. 111- 12; Alfred Mellinek, Don Isaac Abravanel: His Life and Time (London: Jewish Religious Educational Publications, 1952); and Erwin I. J. Rosenthal, "Don Isaac Abravanel: Financier, Statesman and Scholar 1437-1937," Bulletin of the John Rylands Library 21 (1937), 445-78 - repr. in idem, Studia Semitica vol. 1: Jewish Themes (Cambridge: Cambridge University Press, 1971), 21-56, and in Judaism, Philosophy, Culture: Selected Studies by E. I. J. Rosenthal (Richmond: Curzon, 2001), 21-54. Literature on Abravanel's political thought is extensive. In addition to the literature mentioned on pages 3 and 4 see the following studies by Abraham Melamed, "The De-Legitimation of Monarchy in Don Isaac Abravanel's Political Thought," in The Legitimation of Political Power Medieval Thought, ed. C. López Alcaide et al. (Turnhout: Brepols, 2018), 239-52; "The Problem of Political Disobedience in Isaac Abravanel's Biblical Commentaries," in Religious Obedience and Political Resistance in the Early Modern World: Jewish, Christian and Islamic Philosophers Addressing the Bible, ed. Luisa Simonutti (Turnhout: Brepols, 2014), 53-70; Wisdom's Little Sister: Medieval Jewish Political Thought (Raanana [Israel]: Open University Press, 2011), 242-81 
1481, r. 1438-1481) treasurer, but after Afonsos's death, he was accused by the former's son and successor João II (1455-1495, r. 1481-1495) of being implicated in the plot of Ferdinand II (1430-1483, r. 1478-1483), the Duke of Braganza, against the crown. Abravanel's property was confiscated, and in 1483 he fled to Castile, where he soon entered into the service of King Ferdinand V (1452-1516, r. 1474-1504) and Queen Isabella (14511504, r. 1474-1504) and was entrusted with the collection of revenues. Abravanel's efforts to persuade the king to revoke the edict about the expulsion of the Jews from Spain in 1492 bore no fruit. ${ }^{65}$ Subsequently, he left Spain for Naples, where he entered the service of King Ferrante I (1423 -1494, r. 1458-1494). Following the conquest of the city by the French army in 1495, he moved to Sicily. In 1503, he settled in Venice, where he was destined to play a major role in trade negotiations between that city and Portugal.

Abravanel refutes previous thinkers who highlight the merits of monarchical rule (unity, continuity, and absolute authority) and parallel the king's function in the body politic to that of the heart in a living organism or to the relation of the First Cause to the universe. He also dismisses the association between God's rule over the world and political absolutism as inapplicable and logically fallacious. Instead, he points out that it is impossible to draw a reference from God, a necessary existence, for human beings, who

[in Hebrew]; The Philosopher-King in Medieval and Renaissance Jewish Political Thought (Albany, NY: State University of New York Press, 2003), 62-63, 67-74, 113-22; as well as Cedric Cohen Skalli, "Don Isaac Abravanel and the Conversos: Wealth, Politics, and Messianism," Journal of Levantine Studies 6 (2016): 43-69; idem, "Abravanel's Commentary on the Former Prophets: Portraits, Self-Portraits, and Models of Leadership," Jewish History 23 (2009), 255-80; Ágoston Schmelowszky, "Messianic Dreams and Political Reality: The Case of Don Isaac Abravanel," in Monotheistic Kingship: The Medieval Variants, ed. Aziz Al-Azmeh and János M. Bak (Budapest: Central European University, Department of Medieval Studies, 2004), 137-54; Aviezer Ravitzky, Religion and State in Jewish Philosophy: Models of Unity, Division, Collision and Subordination (Jerusalem: The Israel Democracy Institute, 2002), 85-121; Marianne Luijken Gevirtz, "Reflections on Leadership in Isaac Abravanel's Commentary on the Blessing of Jacob (Gen 49:1-28)" (Ph.D. diss., Hebrew Union College-Jewish Institute of Religion, 1996); Rochelle L. Millen, "Isaac Abravanel's Concept of Monarchy," Shofar 10 (1992), 47-61; Marianne Awerbuch, Zwischen Hoffnung und Vernunft: Geschichtsdeutung der Juden in Spanien vor der Vertreibung am Beispiel Abravanels und Ibn Vergas (Berlin: Institut Kirche und Judentum, 1985), 3847; Solomon Gaon, "Don Isaac Abrabanel's Concept of Kingship," The American Sephardi 7-8 (1975), 45-49; Efraim E. Urbach, "Die Staatsauffassung des Don Isaak Abrabanel," Monatsschrift für Geschichte und Wissenschaft des Judentums 81 (1937), 257-70; and Salomon Lévy, La cité humaine d'après Isaac Abravanel (Diss., University of Strasbourg, 1970).

${ }^{65}$ Elias Lipiner, Two Portuguese Exiles in Castile: Dom David Negro and Dom Isaac Abravanel (Jerusalem: The Magnes Press, 1997), 46-79; Ephraim Shmueli, Don Isaac Abrabanel and the Expulsion from Spain (Jerusalem: Bialik Institute, 1963) [in Hebrew]; and Haim Beinart, The Expulsion of the Jews from Spain, trans. from the Hebrew Jeffrey M. Green (Oxford: Littman Library of Jewish Civilization, 2002). See, in general, also Maria José Pimenta Ferro Tavares, Os Judeus em Portugal no século XIV (Lisbon: Universidade Nova de Lisboa, Facultade de Ciências Sociais e Humanas, 1982), 1: 215-395. 
represent merely a possible existence. ${ }^{66}$ Abravanel then proceeds to counter the analogy between the dominant function of the heart in the living organism and that of the ruler within the political community. Drawing on Galen's physiological theory, he refers to the existence of three principal organs in the human body, i.e., of the heart, the brain, and the liver, instead of one. ${ }^{67}$

Abravanel and Marsilius are alike in stressing that it is possible to have a plurality of rulers acting together. With regards to the argument that the institution of kingship is a guarantee of continuity, Abravanel observes that this objective is better served by temporary leadership, as this renders the ruler's conduct subject to control and to punishment by their successors. Finally, Abravanel stresses that one man in the position of a monarch is more prone to wrong-doing than are multiple individuals. ${ }^{68}$

As indicated previously, Aristotle's doctrine of the sovereignty of the multitude is premised on his idea of collective wisdom. A similar notion of collective wisdom (or prudence) underpins Marsilius' thesis that the laws should be generated by the entire body of the citizenry or their "weightier" part, since truth is more easily reached through the cumulative endeavors of a number of persons. ${ }^{69}$ Abravanel similarly grounds his argumentation in favor of collective leadership in the Aristotelian notion of collective wisdom, but relies on the Metaphysics instead of the Politics. Abravanel does not seem to have had access to William of Moerbeke's (ca. 1215-1286) Latin translation of the Politics (1260s) and all his references to the Politics were most probably mediated by Thomas

${ }^{66}$ Comm. on Deut. 17.14; Ravitzky, Religion and State in Jewish Philosophy, 107, 110; The Jewish Political Tradition, vol. 1: Authority, 150; Medieval Political Philosophy: A Sourcebook, ed. Ralph Lerner and Muhsin Mahdi (New York: Free Press of Glencoe, 1963), 265. See also Avraham Melamed, “Isaac Abravanel and Aristotle's Politics: A Drama of Errors," Jewish Political Studies Review 5 (1993), $55-75,64$.

67 Comm. on Deut. 17.14; Ravitzky, Religion and State in Jewish Philosophy, 110; The Jewish Political Tradition, vol. 1: Authority, 151; Netanyahu, Don Isaac Abravanel, 173. For further discussion, see Abraham Melamed, "The Organic Theory of the State in Medieval and Renaissance Jewish Political Thought," in Ideal Constitutions in the Renaissance, ed. Heinrich C. Kuhn and Diana Stanciu (Frankfurt a. M.: Peter Lang, 2009), 117-51, 140-45 - repr. in idem, Wisdom's Little Sister/2012, 140-74. On Galen's embryology, consult Diethard Nickel, Untersuchungen zur Embryologie Galens (Berlin: Akademie-Verlag, 1989); Rudoph E. Siegel, Galen's System of Physiology and Medicine: An Analysis of his Doctrines and Observations on Blood Flow, Respiration, Tumors and Internal Diseases (Basel and New York: Karger, 1968). Consider also Syros, Marsilus of Padua at the Intersection of Ancient and Medieval Traditions of Political Thought, 108-10.

${ }^{68}$ Comm. on Deut. 17.14; Medieval Political Philosophy: A Sourcebook, ed. Lerner and Mahdi, 266; Netanyahu, Don Isaac Abravanel, 174.

${ }^{69}$ Comm. on I Sam. 8.4; Aristotle, Metaphysics, 993 30-993b2. See also ibid., 993 ${ }^{\mathrm{b}} 1-2$; as well as $O n$

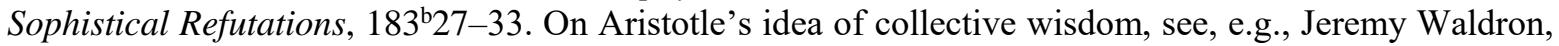
"The Wisdom of the Multitude: Some Reflections on Book 3, Chapter 11 of Aristotle's Politics," Political Theory 23 (1995), 563-84; J. T. Bookman, "The Wisdom of the Many: An Analysis of the Arguments of Book III and IV of Aristotle's Politics," History of Political Thought 13 (1992), 1-12. 
Aquinas or other Christian authors. ${ }^{70}$ Intriguingly, Marsilius makes a similar reference to the Metaphysics to illustrate the relationship between civil legislation and the accumulated wisdom of the citizenry. ${ }^{71}$

According to Abravanel, the authority of the ruler should be restricted and exercised in accordance with the laws and the public good, and his transgressions should receive proper punishment from his successors. Abravanel explains that Rome rose to world dominance while it was ruled by consuls serving temporary terms, but started declining as soon as Caesar took over power. Abravanel points to various Italian cities, such as Venice, Florence, Genoa, Lucca, Siena, and Bologna, in which government is exercised by officials appointed for a fixed term. Such cities are able to conquer other lands thanks to their wisdom, perspicacity, and expertise. ${ }^{72}$

Just as Ptolemy of Lucca contrasts the functions of the king and the rector (by which he means the head of constitutional government), so too Abravanel engages in a detailed comparison of the prerogatives of the king with those of the judge. The points of comparison chosen by the two authors, moreover, are very similar: first, the king's rule is hereditary and based on right of birth, whereas the judge's is not. Second, the king's principal task is to command the army in war. He also has the final say in the administration of justice and legal issues and is entitled to act according to his discretion in cases of emergency and in response to the needs of the particular circumstances, even if he is forced to violate the laws. ${ }^{73}$ Finally, the king is entitled to raise taxes and revenues from his

70 On this point and on Abravanel's exposure to Aristotle's political ideas, see the following studies by Av[b]raham Melamed: "Aristotle's Politics in Medieval and Renaissance Jewish Political Thought," in Well Begun is Only Half Done: Tracing Aristotle's Political Ideas in Medieval Arabic, Syriac, Byzantine, and Jewish Sources, ed. Vasileios Syros (Tempe, AZ: ACMRS, 2011), 145-86, 170-80 repr. in idem, Wisdom's Little Sister/2012, 78-119; "Isaac Abravanel and Aristotle's Politics"; and idem, "Jethro's Advice in Medieval and Early Modern Jewish and Christian Political Thought," Jewish Political Studies Review 2 (1990), 3-41- repr. in idem, Wisdom's Little Sister/2012, 175-211. The reception of Aristotle's moral and political thought in the Iberian Jewish tradition is surveyed in JeanPierre Rothschild, "La contestation des fins de la politique selon Aristote chez quelques auteurs juifs du moyen âge tardif en Espagne," in Well Begun is Only Half Done, 187-221. For the Christian/Latin tradition, consult Ann M. Giletti, "The Reception of Aristotelian Philosophy among Latin Iberian Scholars during the Thirteenth and Early Fourteenth Centuries" (Ph. D. diss., University of London, 2002).

${ }^{71}$ DP I.xi.3. On this point, see also Syros, Marsilus of Padua at the Intersection of Ancient and Medieval Traditions of Political Thought, 89.

72 Comm. on Deut. 17.14; Ravitzky, Religion and State in Jewish Philosophy, 108-9; The Jewish Political Tradition, vol. 1: Authority, 151; Medieval Political Philosophy: A Sourcebook, ed. Lerner and Mahdi, 266-67; Netanyahu, Don Isaac Abravanel, 174.

${ }^{73}$ Comm. on Deut. 17.14; Netanyahu, Don Isaac Abravanel, 175. By comparing the office of the king with that of the judge Abravanel implicitly reworks the biblical narrative, in which these two offices are chronologically distinct (i.e. an era of judges followed by an era of kings). I owe this remark to Daniel Stein Kokin. 
subjects, both for his own purposes and for war-time expenses; no subject has the right to evade taxation. Stealing from the public fund entails the death sentence, and the property and the funds of the executed devolve to the king. The same applies to the land that the king acquires through conquest. People are obligated to pay more respect to the king than to a judge. It is also strictly prohibited for any subject to sit on the king's throne, ride his horse, use his scepter and his utensils, or marry his widow. ${ }^{74}$

But even if the king's authority is subject to legal constraints and his actions do conform to the laws, the very fact that royal government is perceived to symbolize unity, dynastic continuity, and absolute power indicates that the king's power is undivided and that all his decisions have the power of law. The king is, hence, subject to the laws only in theory, because, in practice, his power remains unfettered: he can perform illegal acts without fearing the intervention of other authorities or officeholders; and he possesses the power to annul the verdicts pronounced by judges, whereas no judge has the right to question or challenge the king's decisions. ${ }^{75}$ The only guarantee that the king will abide by the laws and exercise righteous government lies in his moral virtue. For this reason, Abravanel recommends that only those who have pure intentions, shun sin, and exhibit moral integrity and modesty in their conduct be elected to the royal office. ${ }^{76}$ The true ruler ought to be a paragon of moral excellence and serve as an example to others and conduct himself justly and lawfully. ${ }^{77}$ The king should be the personification of respect for laws, fear of God, and modesty; ${ }^{78}$ he should possess exhibit justice, gentleness, love of peace, and mercy. ${ }^{79}$ In seeking to promote the welfare of his subjects, the ruler, though appearing to be their master, effectively becomes their servant. ${ }^{80}$

Abravanel agrees with Marsilius that a person endowed with the aforementioned qualities and virtues is exceedingly rare. Like Marsilius, he claims that no one can resist the temptations of royal authority - each, in the end, will be inclined to use this authority to further his own ends. Given that the king is able to use his subjects' manpower and property according to his own will and understanding, precautions must be taken to ensure that he does not fall prey to his desires and overstep the limits of his authority: by prohibiting him from taking many women and having many horses; by making sure that he does not engage

\footnotetext{
${ }^{74}$ Comm. on Judges, intro.; Netanyahu, Don Isaac Abravanel, 177.

${ }^{75}$ Comm. on Judges, intro.

${ }^{76}$ Comm. on Deut. 17.14; Netanyahu, Don Isaac Abravanel, 177.

${ }^{77}$ Comm. on Judges, 10.14.

${ }^{78}$ Comm. on Deut. 17.14.

${ }^{79}$ Comm. on Deut. 17.14; Comm. on Judges, 10.14.

${ }^{80}$ Comm. on Judges, 10.14; Netanyahu, Don Isaac Abravanel, 177-78.
} 
in unnecessary wars and conquests; and rendering him immune to the desire to accumulate wealth and property through robbery and extortion. ${ }^{81}$ Kingship is by its very nature doomed to lapse into a type of rule founded on arbitrary laws and violence. As such, laws serve as a means to curb the ruler's actions and restrain or temper his desires. ${ }^{82}$

As noted above, Marsilius' reading of Aristotle's Politics culminates in the vision of the entire body of the citizens as the locus of ultimate authority within the political community. In a similar vein, Abravanel articulates a proto-republican conception of political organization by setting forth a novel interpretation of Jethro's story (Exod. 18: 1327). ${ }^{83}$ In his commentary on Exodus, Abravanel glosses on Moses' selection and appointment of "rulers of thousands, rulers of hundreds, rulers of fifties, and rulers of tens." As Abravanel phrases it, in every large polity there are matters that should be decided by a body of a thousand persons appointed for this purpose, others to be adjudicated with the consent and advice of a hundred advisors, or of fifty or forty persons, and some that can be entrusted to only ten persons. According to Abravanel's interpretation, Moses created four separate councils composed of rulers of thousands, hundreds, and tens, respectively. Each of these bodies was in charge of a fraction of the population and had a clearly demarcated sphere of authority. As a result, every official adjudicated truth and peace; but that would not have been the case had a single individual were in charge of tens of thousands of person, because the variety of the cases and matters and the large size of his constituency would have led his judgment astray. In commenting on Exodus, Abravanel explains that Moses stipulated that the officials be appointed by the people, although he was advised by Jethro to select and appoint rulers according to his discretion. ${ }^{84}$

In Deut. 1, Moses exhorts the Israelites to select sagacious, discerning, and able men and appoint them as their leaders, whereas in Deut. 18 Jethro calls upon Moses to do so. Abravanel capitalizes on this difference between the two variants of the political reform tale

${ }^{81}$ Comm. on Judges, intro.; and Comm. on Deut. 17.14; Netanyahu, Don Isaac Abravanel, 178. Many of the provisions laid down by Abravanel derive from from Deut. 17.14-20 (Law of Kings).

${ }^{82}$ Comm. on I Sam. 8.4.

${ }^{83}$ On the following, see also Melamed, "Jethro's Advice in Medieval and Early Modern Jewish and Christian Political Thought," 3-41; idem, "The Attitude Towards Democracy in Medieval Jewish Philosophy," Jewish Political Studies Review 5 (1993): 33-56, 49-51 - repr. in idem, Wisdom's Little Sister/2012, 120-39; Netanyahu, Don Isaac Abravanel, 170. On the use of the Jethro episode in Castilian political discourse, see François Foronda, "Le conseil de Jéthro à Moïse: le rebond d'un fragment de théologie politique dans la rhétorique parlementaire castillane," Médiévales 57 (2009) [= Langages politiques, XII $-X V^{e}$ siècle, ed. Aude Mairey], 75-92.

${ }^{84}$ Ravitzky, Religion and State in Jewish Philosophy, 100-1; Netanyahu, Don Isaac Abravanel, 170; Medieval Political Philosophy: A Sourcebook, ed. Lerner and Mahdi, 259-61. 
to advance a "republican" interpretation. ${ }^{85}$ Furthermore, there are, in Abravanel's view, certain matters that can be decided only by a group of ten persons who have the final word in civic affairs. Whereas in the original story the aforementioned magistrates performed a judicial function, Abravanel assigns to them legislative and governing power as well. In addition, Abravanel reverses the Mosaic hierarchy and inverts the biblical meaning of "rulers of fifties" etc. The plurals of all these numbers indicate that individual judges (sarim) were appointed to oversee groupings of one thousand, one hundred, fifty, etc. Abravanel, however, transforms these individual judges into legislative bodies consisting of one thousand, one hundred, fifty, etc., thereby giving a republican twist to the Jethroic political order. Abravanel further explains that the larger the number of the officials, the more effective the government. Just as Marsilius depicts the ruler/government as the executive agent of the entire civic body, so too Abravanel stresses that the ruler and officeholders are servants of the people, rather than their overlords. ${ }^{86}$

Abravanel's ideas on kingship were anticipated in certain ways by Isaac Arama (ca. 1420-94), a prominent rabbi, preacher, and political philosopher, who operated in the Spanish context (Aragon) and moved to Naples in 1492, after the expulsion of the Jews from Spain. Arama's most important work the 'Akedat Yitzhak (Binding of Isaac, ca. 1480, published in 1522) is a collection of sermons, philosophical homilies, and commentaries on the Bible, and includes a discussion of election as a determinant of the legitimacy of kingship. The exemplary polity, as envisioned by Arama, is one founded on law and order and aims at the well-being and security of all its members. A legal system and an elected ruler reflect the character of a given society. The ruler's foremost task is to uphold unity and justice, create all the physical and material conditions conducive to the welfare of his people. He is also expected to provide the members of society with the requisite means that will allow them to fulfill their spiritual and intellectual potential. The ruler ought to embody all the moral, spiritual, and intellectual qualities related to righteous government, especially political wisdom. Moreover, he should to strive to secure full religious and public legitimacy and elicit the support of his subjects. Although Arama subscribes to the ideal of the Davidian dynastic reign, he opposes hereditary rule. He advocates instead an elected

\footnotetext{
${ }^{85}$ In the more "republican" version of the tale, the role of Jethro is elided and taken over by God, a development that evokes a link to Niccolò Machiavelli's (1469-1527) idea that the voice of a people can be likened to that of God (Discourses on Livy, I.58).

${ }^{86}$ Comm. on Exod. 18.24; Medieval Political Philosophy: A Sourcebook, ed. Lerner and Mahdi, 26061; Netanyahu, Don Isaac Abravanel, 170, 177-78.
} 
ruler who is appointed on the people's approval for a fixed period. ${ }^{87}$

Abravanel also establishes an analogy between the biblical text, which refers to heads of thousands, hundreds, fifties, and tens, and Venice's governmental structure. He mentions that the councils instituted by Moses are exemplified by the Great Council (Consiglio Maggiore), which is composed of more than a thousand members; the Consiglio dei Pregadi, i.e., the Senate, which is made up of around two/three hundred persons and served as the key deliberative and legislative organ; the Council of Forty (Quarantia), a special tribunal, which consists of forty councilors and was entrusted with the adjudication of crimes against the state; and the Council of Ten (Consiglio dei Dieci), which includes ten officials, who are selected from among the leading citizens on an annual basis and are in charge of economic and foreign affairs as well as of the investigation of criminal cases. ${ }^{88}$

Power in Venice resided with the Consiglio Maggiore, which comprised the male members of all patrician families. As with the Jethro story, Abravanel offers a description of Venice's governmental organization with strong republican overtones. In doing so, he seeks to underscore the analogies to his proposed system of government as being grounded in collective leadership. By depicting Venice as a mixed constitution, Abravanel drew upon the "Myth of Venice," which was propounded in earlier literature on Venetian political

\footnotetext{
${ }^{87}$ The following account is based on Michael N. Rony, "Social and Political Ideas in Early Modern Jewish Philosophical Commentaries on the Story of the Tower of Babel," in Tradition, Heterodoxy, and Religious Culture: Judaism and Christianity in the Early Modern Period, ed. Chanita Goodblatt and Howard Kreisel (Beer-Sheva: Ben-Gurion University of the Negev Press, 2006), 167-84, 170-75; and idem, Issues in Political Philosophy in Rabbi Yitzhak Arama's Commentary on the Torah (MA thesis, Bar-Ilan University, 2000), 64-68 [in Hebrew]. Consider also Akeydat Yitzchak: Commentary of Rabbi Yitzchak Arama on the Torah, trans. and condensed by Eliyahu Munk (Jerusalem and New York: Lambda Publishers, ${ }^{\text {rd }}$. rev. ed. 2001), vol. 1: Bereshit-Shemot, 86-7, 115, 198, 437-41; vol. 2: VayikraBamidbar-Devarim, 749, 756-60, 849-54; as well as Bernard Septimus, "Yitzhak Arama and Aristotle's Ethics," in Jews and Conversos at the Time of Expulsion: Collection of Essays, ed. Yom Tov Assis and Yosef Kaplan (Jerusalem: Zalman Shazar Center for Jewish History, 1999), 1-24; Menachem M. Kellner, "Gersonides and his Cultured Despisers: Arama and Abravanel," Journal of Medieval and Renaissance Studies 6 (1976): 269-96, esp. 273-78 - rev. repr. in idem, Torah in the Observatory: Gersonides, Maimonides, Song of Songs (Boston, MA: Academic Studies Press, 2010), 305-32; and Israel Bettan, Studies in Jewish Preaching: Middle Ages (Cincinnati, OH: Hebrew Union College Press, 1939; repr. Lanham, MD, and London: University Press of America, 1987), 130-91.

${ }^{88}$ Comm. on Exod. 18.13; Ravitzky, Religion and State in Jewish Philosophy, 100; Netanyahu, Don Isaac Abravanel, 170. On the ways in which Abravanel's political theory reflects political practices in early modern Venice, see Umberto Piperno, "Abravanel e le istituzioni politiche della Repubblica di Venezia," Rassegna Mensile di Israel 59 (1993), 154-70; Baer, "Don Isaac Abravanel and His Relation to Problems of History and Politics"; and Herbert Finkelscherer, "Quellen und Motive der Staats- und Gesellschaftsauffassung des Don Isaak Abravanel," Monatsschrift für Geschichte und Wissenschaft des Judentums 81 (1937), 496-508.
} 
organization $^{89}$ and reverberates with subsequent Jewish political writers, such as David de Pomis (1525-1588) and Simone Luzzatto (1583-1663)..$^{90}$

\section{Conclusions}

Unlike Marsilius, who accepts law-bound kingship as a legitimate constitutional form, Abravanel, in effect, takes a more radical stance and elides the distinction between absolute and limited royal authority and between kingship and tyranny, as expounded in Aristotle's Politics and applied, for instance, by the apostate bishop Paul of Burgos (ca. 1351-1435) in his commentary on the Bible. ${ }^{91}$ Abravanel is primarily concerned with illustrating the risks

${ }^{89}$ Such as Pier Paolo Vergerio's De Republica Veneta (written between 1398 and 1400); George of Trebizond's Preface to the Latin translation of Plato's Laws (1452); Giovanni Caldiera's De praestantia venetae politiae (1473); Francesco Diedo's Defensio pro re publica Veneta (1481); and Domenico Morosini's De bene instituta re publica (ca. 1500). On the medieval and early modern reception of the idea of mixed constitution, see, e.g., James M. Blythe, Ideal Government and the Mixed Constitution in the Middle Ages (Princeton, NJ: Princeton University Press, 1992); and Le Gouvernement mixte: De l'idéal politique au monstre constitutionnel en Europe (XIIIe-XVIIe siècle), ed. Marie Gaille-Nikodimov (Saint-Etienne: Publications de l'Université de Saint-Étienne, 2005). On the "Myth of Venice," see Edward Muir, Civic Ritual in Renaissance Venice (Princeton, NJ: Princeton University Press, 1981); Craig Kallendorf, Virgil and the Myth of Venice: Books and Readers in the Italian Renaissance (Oxford: Clarendon Press, 1999); Robert Finley, "The Immortal Republic: The Myth of Venice during the Italian Wars (1494-1530)," Sixteenth Century Journal 30 (1999), 931-44; Giovanni Silvano, La 'Republica de' Viniziani.' Ricerche sul repubblicanesimo veneziano in età moderna (Florence: Leo S. Olschki, 1993); Felix Gilbert, "The Venetian Constitution in Florentine Political Thought," in Florentine Studies: Politics and Society in Renaissance Florence, ed. Nicolai Rubinstein (Evanston, IL: Northwestern University Press, 1968), 463-500; Franco Gaeta, "Alcune considerazioni sul mito di Venezia," Bibliothèque d'Humanisme et Renaissance 23 (1961), 58-75; and Gina Fasoli, "Nascita di un mito," in Studi storici in onore di Gioacchino Volpe per il suo 80 compleanno (Florence: Sansoni, 1958), 1: 445-79.

${ }^{90}$ For further discussion and references, see Giuseppe Veltri, Renaissance Philosophy in Jewish Garb: Foundations and Challenges in Judaism on the Eve of Modernity (Leiden and Boston, mA: Brill, 2009), 194-220; Guido Bartolucci, "Venezia nel pensiero politico ebraico rinascimentale: Un testo ritrovato di David de Pomis," Rinascimento 44 (2004), 225-47; Benjamin C. I. Ravid, "Between the Myth of Venice and the Lachrymose Conception of Jewish History: The Case of the Jews of Venice," in The Jews of Italy: Memory and Identity, ed. Bernard D. Cooperman and Barbara Garvin (Bethesda, MD: University Press of Maryland, 2000), 151-92, esp. 157-59 - repr. in idem, Studies on the Jews of Venice, 1382-1797 (Aldershot and Burlington, VT: Ashgate, 2003), no. IX; Abraham Melamed, "The Myth of Venice in Italian Renaissance Jewish Thought," in Italia Judaica: Atti del I convegno internazionale. Bari 18-22 maggio 1981 (Rome: Ministerio per i beni culturali e ambientali, 1983), 401-13 - repr. in idem, Wisdom's Little Sister/2012, 230-43.

${ }^{91}$ Funkenstein, Perceptions of Jewish History, 160, 164-65; Aviezer Ravitzky, "Political Philosophy: Nissim of Gerona versus Isaac Abrabanel," in idem, History and Faith: Studies in Jewish Philosophy (Amsterdam: J. C. Gieben, 1996), 46-72, 48, 54 [first published as "Kings and Laws in Late Medieval Jewish Thought: Nissim of Gerona vs. Isaac Abrabanel," in Scholars and Scholarship in Jewish History: the Interaction Between Judaism and Other Cultures, ed. Leo Landman (New York: Michael Scharf Publication Trust of the Yeshiva University Press, 1990), 67-90. On Paul of Burgos, see Judith C. Krieger, "Pablo de Santa María: His Epoch, Life and Hebrew and Spanish Literary Production" (Diss., University of California Los Angeles, 1988); Luciano Serrano, Los conversos D. Pablo de Santa María y D. Alfonso de Cartagena, obispos de Burgos, gobernantes, diplomáticos y escritores (Madrid: CSIC, 1942) Cesare Vasoli, "Quadro d'insieme," in: La cultura ebraica all'epoca di Lorenzo il Magnifico: 
associated with perpetual rule and government exercised by one person alone. Marsilius, on the other hand, acknowledges that kingship can be a healthy or legitimate mode of rule. More crucially, Marsilius differs from Abravanel in advocating the separation of the spiritual and temporal powers and the subordination of the latter to the former.

Despite these differences, Marsilius and Abravanel are committed to the notion of the ruler as the executive agent of the civic body. Both writers, moreover, diverge from earlier political writers and bring the potential hazards of perpetual rule into sharper relief; ${ }^{92}$ both, likewise, challenge the indispensability of kingship for societal stability and cohesion. Abravanel goes one step further: he rejects the analogy between the position of the king in the body politic and the heart's function in the living organism, deploying Galen's physiology in lieu of Aristotle's biology, and points to the existence of three principal organs, rather than one, in the human body.

Abravanel intersects with Marsilius in postulating a correlation between collective leadership and the perfection of knowledge produced by successive generations. Similar to the way in which Abravanel transforms his biblical sources, Marsilius attempts a novel interpretation of Aristotle's doctrine of collective wisdom in order to posit the entire body of the citizens as the sole legitimate source of legislative and governmental authority. Marsilius' and Abravanel's critique of perpetual rule could have been inspired by the political and social conditions that prevailed in late medieval Italy. A comparative exploration of their respective approaches to kingship can help us revisit the impact of the communal culture and values of the Italian cities on the genesis and trajectories of protoRepublican ideas in the Christian/Latin and Jewish political traditions and the evolution of modern republican ideas.

Celebrazioni del V centenario della morte di Lorenzo il Magnifico, ed. Dora Liscia Bemporad and Ida Zatelli (Florence: L. S. Olschki, 1998), 3-16.

${ }_{92}$ Compare Reuven Kimelman, "Abravanel and the Jewish Republican Ethos," in Commandment and Community: New Essays in Jewish Legal and Political Philosophy, ed. Daniel H. Frank (Albany, NY: SUNY Press, 1995), 195-216, who challenges the idea that Abravanel's republicanism constitutes a rupture with the antecedent Jewish political tradition and points to precedents in earlier Jewish writings. See also Yair Lorberbaum, Disempowered King: Monarchy in Classical Jewish Literature (New York: Continuum, 2011); Gerald J. Blidstein, "The Monarchic Imperative in Rabbinic Perspective," AJS Review 7/8 (1982/1983): 15-39. 